\title{
Legal Aspect of an Agreement Cancellation in the State of Majeure Force during the Pandemic Covid-19
}

\author{
Mifta Hulzannah ${ }^{1}$, Sriono $^{2}$, Elviana Sagala ${ }^{3}$ \\ ${ }^{1,2,3}$ Law Study Program , Faculty of Law, Labuhanbatu University, Indonesia \\ Sriono.mkn@gmail.com
}

\begin{abstract}
Many parties can cancel an agreement or contract during the Covid-19 pandemic in Indonesia. WHO Director General, Tedros Adhanom Ghebreyesus determined the status of Corona Virus Disease 2019 (Covid-19) as a Pandemic This happened because the government issued Presidential Decree No. 12 of 2020 concerning the Determination of Disaster in the Spread of Corona Virus Disease 2019 (COVID-19) as a National Disaster. The covid-19 pandemic falls into the force majeure category or a state of force because it causes the economic sector to experience a decline. The community cannot do work as usual, all activities carried out are very limited. A contract is an agreement made by the parties in written form. An agreement is an act that binds one or more people to one or more people. This event resulted in a legal relationship between the parties, which included rights and obligations. Circumstances compel or force majeure may be earthquakes, fires, floods, landslides, wars, military coups, embargoes, epidemics, and so forth. In the time of the corona pandemic which is currently hitting all parts of the world, of course, it has an impact on the implementation of an agreement I contract. The purpose of this paper is to examine the force majeure in an agreement that occurs during the corona virus pandemic, which cannot automatically be used as a reason for cancellation of an agreement / contract, but can be used as a way to negotiate in canceling or changing the contents of the agreement / contract. The contract / agreement is canceled unilaterally without regard to the sense of justice, in accordance with Article 1338 paragraph (1) of the Civil Code, it is stated that the contract is a law for the parties. So the cancellation of the contract with due regard to aspects in the law and Article 1338 paragraph (1) of the Civil Code cannot be carried out in a covid-19 pandemic force majeure situation. The parties are required to carry out good faith in accordance with Article 1338 of the Civil Code by reviewing the agreement / contract or renegotiating by adding a contract clause to postpone carrying out obligations.
\end{abstract}

\section{Keywords} agreement; force majeure; legal aspects

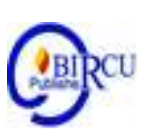

\section{Introduction}

Pandemi is increasingly spreading in Indonesia with the spread of the Covid-19 virus which causes all community activities to be increasingly disrupted. This includes corporate activities, both national and global, which have also received a huge impact due to the outbreak of Covid-19. In a business environment, failure to fulfill an agreement or default does not apply if a person who does not meet the achievement can prove that there is an obstacle that cannot be avoided, for example the result of a natural disaster. With the Covid-19 outbreak, which is a global pandemic, can it immediately be used as an excuse as a force majeure for not carrying out the agreement. The provisions regarding Force 
Majeure are generally contained in Article 1244 and Article 1245 of the Civil Code, which essentially frees the debtor from all costs, losses and interest as long as the debtor can prove a force majeure.

Director-General of WHO, Tedros Adhanom Ghebreyesus which is the World Health Organization set the status of Corona Virus Disease 2019 (Covid-19) as P andemi, with more merebakny a virus spread Covid 19th o leh Therefore, the Indonesian government has determined that the pandemic corona's as a type of disease that can cause health emergencies to the community (Gorontalo Province Health Office). The Covid-19 pandemic has affected the banking sector, such as a decline in financing, this decline was due to a decrease in the ability of customers to make payments (Ichsan et al., 2021).

Contract comes from the term of the agreement. A contract is an action carried out by two or more parties in which each party is required to perform an achievement. Meanwhile, the meaning of business is actions that have commercial value. So that what is meant by a business contract is a written agreement in which the content or substance is agreed upon by the parties bound to it, and has commercial value. The performance of a contract or business agreement results in the birth of a legal relationship. In practice, a contract does not always fulfill its aims and objectives. This can result in default, both by the creditor and the debtor. Apart from that, it can also be due to coercion, mistakes, fraudulent acts, or due to force majeure. The failure to achieve the intent and purpose of a contract due to force majeure, generally results in an event in which a person is unable to perform his obligations due to events beyond his reach to avoid the event. Force majeure is one of the concepts in civil law and its existence is accepted as a principle in law, especially in the scope of contract law (Subekti, 1991).

In the law of agreement, in order to determine the condition of the debtor's default, a subpoena / warning letter / statement of negligence to the debtor is required. Somasi is a warning letter / notification from the creditor to the debtor that the debtor has neglected to carry out his obligations in accordance with what has been agreed in the agreement. With the provision of credit that will be carried out by creditors and collateral that will be fulfilled by the debtor, then objects are loaded with fiduciary guarantees.(Sriono, 2019).

In his book entitled "Introduction to International Law " (Mochtar Kusumaatmadja \& Etty R Agoes, 1999) the existence of a force majeur or vis major can be accepted as an excuse for not fulfilling obligations due to the loss or disappearance of an object which is the main objective of the agreement. This situation is aimed at physical and legal implementation, not only due to difficulties in carrying out its obligations . ( Mieke Komar Kantaatmadja , 2010) also provides a similar view, namely:

a) Changes in circumstances did not exist at the time of the formation of the agreement;

b) The change concerns a condition which is fundamental to the agreement;

c) The changes cannot be predicted in advance by the parties;

d) The result of the change must be radical, so that it changes the scope of the obligations that must be carried out according to the agreement;

e) The use of this principle cannot be applied to border agreements and also changes in circumstances resulting from violations committed by the party submitting the claim. The condition of force or force majeure in an agreement is regulated in the Civil Code (KUHPerdata) Article 1244 and Article 1255. If it is further examined, the regulations regarding force majeure emphasize more on how to reimburse costs, compensation, and interest.

Even so, these provisions can still be used as a reference as a force majeure regulation. In an agreement, a force majeure clause or also known as an overmacht can provide protection to debtors if they experience losses caused by natural disasters (floods, 
earthquakes, rainstorms, hurricanes), power outages, sabotage, war, military coups, epidemics, terrorism, blockades, embargoes, and so on.

The global corona virus pandemic disaster that is currently hitting the economy, especially in the business world, is used as an excuse by business actors not to fulfill their achievements or obligations because of events that are beyond their capabilities. This resulted in many business contracts being automatically changed and even canceled. Given this, the law must be fair, balanced as the principle on which the bankruptcy law and the postponement of debt payment obligations are based, namely the principle of balance, the principle of business continuity, the principle of justice, the principle of integration so that through PKPU it is hoped that it can find a solution in dealing with conflicts that occur so that bad debtors can be avoided and creditors who do not do justice can also be avoided (Elviana Sagala, 2015). The current spread of the corona virus has caused public speculation, especially business people who consider the Presidential Decree Number 12 of 2020 concerning the Determination of Non-Natural Disasters for the Spread of Corona Virus Disease 2019 (Covid-19) as the legal basis for force majeure. Furthermore, this discussion will be further explored regarding the reasons for force majeure in an agreement cancellation, in terms of business contracts that occur during the Covid-19 pandemic.

\section{Research Methods}

This research is a legal research with a normative approach, namely an approach based on the prevailing laws and regulations. Normative legal research is a process to find a rule of law, legal principles, and legal doctrines in order to answer legal issues at hand. The specification of this research is included in the category of legal research which is descriptive analysis specification, which is a study that seeks to describe legal problems, legal systems, and to study or analyze them according to the needs of the research. The data collection method uses secondary data which is carried out through literature studies, namely by reading the applicable laws and regulations, literature books and other documents that are related to the issues to be discussed. Data analysis by processing data obtained from the field and literature data then analyzed qualitatively normative. Normative qualitative analysis, namely data or regulations obtained from the research results are grouped and selected and then connected with the problem to be studied based on its quality and truth so that conclusions will be obtained from the existing problems. ( Peter Mahmud Marzuki, 2010).

\section{Results and Discussion}

\subsection{Agreement / Contract Overview}

An agreement is an event that occurs when the parties promise each other to carry out certain actions. According to Subekti, in his book entitled "Testament Law" says that an agreement is an event when one or more promises to carry out an agreement or mutually promise to carry out something. (Subekti, 1991). The term agreement is often termed a contract term. Contracts or contracts (in English) and overeenkomst (in Dutch) in a broader sense are often referred to as agreement terms. A contract with an agreement is the same term because the point is that the parties agree on the things that are agreed upon and are obliged to comply with and implement them so that the agreement creates a legal relationship called an engagement (verbintenis). Thus, a contract or agreement can create rights and obligations for the parties making the contract and because of that the contract made is seen as a source of formal law (Abdul Rasyid Salim \& Hermansyah, 2007). 
Salim HS said the term agreement is a translation of the word overeenkomst (Dutch) or Contract (English). There are two kinds of theories that discuss the meaning of agreement, namely the old theory and the new theory. Article 1313 of the Civil Code states, "An agreement is an act with one or more parties binding itself to one or more people." The definition of the agreement in Article 1313 is (Salim HS, 2005) :

1) It is not clear because every action can be called an agreement.

2) The principle of consensualism does not appear

3) Dualism in nature

This definition is unclear because in the formulation only acts are mentioned so that what is not a legal act is also called an agreement. To clarify this meaning, it must be looked for in doctrine. According to the old theoretical doctrine, what is called an agreement is a legal act based on an agreement to cause legal consequences. From the definition above, it appears that the principle of consensualism and the emergence of legal consequences (growth or disappearance of rights and obligations).

According to the New Theory put forward by Van Dunne, what is defined as an agreement is "a relationship between two or more parties based on an agreement to cause legal consequences." The new theory, according to Salim HS, does not only look at agreements, but also must be seen from previous or preceding actions . (Salim HS, 2005).

There are three stages in making an agreement according to the new theory, namely:

a) Pracontractual stage, namely the existence of offers and acceptance

b) Contractual stage, namely the agreement between the parties' intentions

c) Post Contractual Stage, namely the implementation of the agreement

1) The elements of the agreement according to the old theory, namely:

a) The existence of legal action

b) Conformity to the statement of the will of several people

c) This agreement of will must be published and declared

d) Legal action occurs because of cooperation between two or more people

e) The corresponding statements of will (wilsverklaring) must be mutually dependent

f) Will is aimed at causing legal consequences

g) Legal consequences for the interests of one at the expense of the other or reciprocal

h) The conformity of the will must take into account the statutory regulations

From the description of the elements of the agreement, it can be understood that there are agreements which are valid and some are not valid. A valid agreement means an agreement that fulfills the said value between the parties who copy bind themselves or promise each other and have the same intention to do certain actions by accepting the risks of each. The agreement of will between the parties is regulated by law.

\subsection{The Terms of the Validity of the Agreement}

In the American Law of Contract, four terms of the validity of the agreement are determined, namely (Salim HS, 2005):

a) There is an offer (offer) and acceptance (acceptance)

b) Mettin of minds (conformity of will)

c) Consideration (achievement)

d) Competent legal parties and legal subject matter.

Meanwhile, in Continental European Law, the terms of the validity of the agreement are regulated in Article 1320 of the Civil Code or Article 1365 of Book IV NBW (New BW) of the Netherlands. Article 1320 of the Civil Code determines four conditions for the validity of the agreement, namely: 
a) There is an agreement (Toesteming or permission) for the two parties.

b) Acting Skills

c) The existence of the Object of the Agreement (Onderwerp Derovereenskomst)

d) The existence of Halal causes (Georloofde Oorzaak)

In the execution of the contract, it is often not possible to go according to what the parties want because in the fulfillment of the achievements it is not carried out in accordance with what has been agreed by both parties. This is because a debtor fails to promise or fails to fulfill obligations in the contract. A party that cannot fulfill the performance in accordance with what has been agreed in the contract can be said to be in default.

Default comes from the Dutch language, namely wanprestatie, which means poor performance. Poor performance means that the achievement is not carried out because of the debtor's fault, either due to intent or negligence. Subekti argues that default is if the debtor (debtor) does not do what he promised (Subekti, 1991). The default (negligence or negligence) of a debtor can be of four types:

a) Not doing what he was supposed to do;

b) Do what he promised, but not as promised;

c) Does what it promises but is too late;

d) Doing something that the agreement is not allowed to do.

It has been previously stated that default can occur when one of the parties to the contract or agreement does not fulfill its obligations. With the default from one of the parties, it results in not carrying out an agreement. Non-fulfillment of obligations by the debtor can be caused by 2 (two) things, namely:

a) Because the debtor has an error.

The debtor is unable to fulfill the obligation to perform due to negligence or deliberate action.

b) Due to force majeure or overmacht.

Circumstances force (force majeure) or coercion is a condition that can lead to the debtor can not meet achievement to creditors. This situation is a condition that cannot be known by the debtor at the time of making the agreement or the situation occurs beyond the control of the debtor.

\subsection{Force Majeure Overview}

The position of force majeure lies in the legal part of the contract. Contract law is part of civil law which focuses on the obligation to carry out its own obligations ( selfimposed obligation ). Circumstances compel or force majeure can be defined as a situation where a debtor is blocked to carry out to carry out his achievements for their event or unforeseen circumstances time of the conclusion of a contract, where the event or circumstance compliance with the obligation of the debtor to the creditor, while the debtor at the time it was not in bad faith. Riduan Syahrani argues that a force majeure is also known as the term overmacht and some call it "force majeure" (Riduan Syahriani, 2006) .

The force majeure regulation contained in the Civil Code does not have an article regulating force majeure for a bilateral contract (a contract made by exchanging promises from the two parties), so there is no general juridical standard that can be used to define the meaning of force majeure. . So to interpret the term force majeure in the Civil Code, it can be interpreted that the regulation regarding force majeure contained in the regulation on compensation, or risk management due to force majeure for one-sided contracts or in the part of special contracts (named contracts) is drawn from theoretical conclusions. law concerning force majeure, doctrine and jurisprudence. Regulations regarding force 
majeure are contained in the Civil Code (KUHPerdata) in Article 1244 and Article 1255. However, there are also several articles apart from those already mentioned which can be used as guidelines for force majeure, namely Articles 1545, 1553, 1444, 1445, and 1460 of the Civil Code. Force majeure is very closely related to the issue of compensation in a contract or agreement. This is because the force majeure brings legal consequences, not only the loss or delay of the obligations in a contract to perform the performance, but the force majeure can free the parties to be able to provide compensation due to the nonperformance of the contract. (Amran Suadi, 2017).

Basically, the regulation in the Civil Code only regulates the issue of force majeure in relation to compensation and interest compensation only. The force majeure is regulated in book III of the Civil Code, Articles 1244 and 1245 which reads:

Article 1244 of the Civil Code:

If there is a reason for that, the debtor must be punished with compensation for expenses, losses, and interest if he cannot prove that the agreement was not or not at the right time due to an unforeseen event or could not be held responsible for him, all of which. that is, if bad faith is not on his side.

Article 1245 of the Civil Code:

It is not the cost of loss and interest, it must be replaced, if due to coercive circumstances or because of an accidental incident the debtor is unable to provide or do something that is required, or because the same things have committed a prohibited act.

In Article 1244 of the Civil Code, it is explained that the payment of compensation costs and interest is linked to the burden of proof, that is, in the event of default, the debtor is punished to pay compensation if he cannot prove that the default was due to unforeseen circumstances or circumstances beyond the ability of the debtor. The debtor must also be ensured that he is not in a state of bad faith because if it is proven that the debtor has bad intentions, he will still be burdened to pay compensation. In addition, the problem of the burden of proof lies with the debtor, so that if he cannot prove the reasons that can exempt from paying compensation, the debtor must pay compensation. So the creditor does not need to be burdened with evidence to be able to claim compensation from the debtor who has defaulted. (Ahmadi Miru, 2016).

Article 1245 of the Civil Code explains the exemption of payment of fees, losses and interest by the debtor if there has been a compelling situation or due to an accidental situation, resulting in the debtor being unable to provide or do something that is required, or because of the same things he has committed an act which is obligatory. forbidden. Basically, it is the same as the previous article, namely explaining the release of the debtor in paying compensation for damages if he fails to perform. The achievement is not carried out due to a compelling or unintentional situation. (Ahmadi Miru, 2016).

In Article 1545 KUHPerdata Book 3 Chapter V explains about the destruction of certain goods that have been promised to be exchanged without the fault of the owner, then the agreement is deemed invalid and the party who has fulfilled the agreement can claim back the goods that he has given in exchange.

In Article 1553 of the Civil Code Book 3 Chapter VII, it is explained that the entire property is destroyed during the lease period due to an accidental incident, then the lease agreement is null and void by law. Meanwhile, if the goods which are used as the object of lease are only partially destroyed, the tenant can choose according to the circumstances, 
will ask for a reduction or will ask for the cancellation of the lease agreement, but in both cases he is not entitled to compensation.

Article 1444 explains the termination of an agreement if certain goods which are the subject of the agreement are destroyed, cannot be traded, or are lost until it is completely unknown whether the goods are still there or not, then the agreement is terminated. This is based on two conditions, namely (Ahmadi Miru, 2016) :

a) Destruction or loss of goods outside or not the fault of the debtor; and

b) The debtor has not been negligent in handing over the goods to the creditor.

Article 1445 explains the obligation to provide rights and claims for compensation regarding said goods to the creditor if the goods owed are destroyed, can no longer be traded, or are lost outside the fault of the debtor. This article explains about the delivery of goods which are the object of the destroyed agreement to the creditor. The destroyed goods should belong to the creditor, but because they were destroyed before being handed over, all claims for compensation originating from the destroyed goods belong to the creditor.

Article 1460 explains that the goods sold are in the form of goods that have been determined, so from the time of purchase, the goods are borne by the buyer, even though the delivery has not been made and the seller has the right to claim the price. From some of the definitions that have been mentioned above, it can be concluded that what is meant by force majeure is a situation or event that occurs outside of human power which can cause the debtor's achievement to be unable to fulfill, and the debtor is not obliged to bear the risk. Matters about compelling circumstances are contained in the provisions governing compensation because according to the legislators, force majeure is a justification ( rechtvaardigingsgrond) to exempt someone from the obligation to pay compensation.

According to the law, there are 3 (three) elements that must be fulfilled to make an event a compelling state, namely :

a) Does not meet achievements;

b) There is a cause that lies outside the debtor's fault; and

c) The causative factor was not foreseen and cannot be accounted for to the debtor.

In the history of thinking about the state of force there are 2 (two) schools or teachings, namely (Mariam Darus Badrulzaman \& et al, 2016):

1) Teaching that is objective ( de objective overmachtsleer ) or absolute

The teaching of an objective forcing situation states that the debtor is in a state of force if it is impossible for anyone to fulfill the achievement (there is an element of impossibility). Classical legal scholars thought that this teaching was focused on the event of a natural disaster or a great accident, so that in such a situation no one could fulfill his achievements. In addition, if there is loss or loss of goods outside of trade, it is considered a forceful situation.

2) Teaching that is subjective (de subjectieve overmachtsleer) or relative

The teaching of subjective coercion states that a compelling state exists and can occur if the debtor is still possible to carry out an achievement but through great difficulty and sacrifice (there is an element of diffikultas) and is unbalanced even using soul power that is beyond human ability or is likely to bring enormous losses, so that in such circumstances the creditor cannot demand the implementation of an achievement. When viewed from the point of view of the time period a condition is in effect, it can be said to be a force majeure, then the state of force can be divided into 2 (two), namely: 
a) Permanent force majeure

A condition is said to be a force majeure as permanent if until whenever an achievement is issued from a contract or agreement, it is not even possible to do it anymore. For example, goods that are the object of the agreement are destroyed outside of the debtor's fault. The destruction of goods makes it impossible for a debtor to carry out his achievements.

b) Temporary force majeure

A condition is said to be a force majeure as temporary in nature if it is not possible to do so for a while in fulfilling the achievements of the issue. For example, because of a certain event. After the situation stops or is over, the achievements that have not been implemented can be fulfilled again.

\subsection{Legal Aspects of a Cancellation of Agreement in Force Majeure during the Covid- 19 Pandemic}

Legal aspects in dealing with contract cancellations in a state of force majeure pandemic Covid-19 in Indonesia have been carried out by the government by making legal policies. Legal policy is an attempt to create good regulations in accordance with the circumstances and situations at a time. Corona viruses are a global pandemic caused many actors - actors attempt to not carry out its obligations. He made this incident an excuse as a force majeure not to carry out the agreement. Even so, using the Covid-19 excuse to claim a force majeure without government policies is difficult to implement.

WHO Director General, Tedros Adhanom Ghebreyesus stated that Covid-19 would be a global pandemic in March 2020. Then in April 2020, the government issued Presidential Decree No. 12/2020 concerning the Determination of Non-Natural Disasters for the Spread of Corona Virus Disease 2019 (Covid-19) as a National Disaster. Non- natural disasters caused by Covid-19 have had an impact on increasing the number of victims, property losses, expanding the coverage of areas affected by disasters, and having implications for broad social and economic aspects in Indonesia. Thus the Presidential Decree has resulted in public speculation, especially business players, that the existence of this regulation can be used as a legal basis for force majeure (Gorontalo Province Health Office).

During the Covid-19 pandemic the government issued Presidential Decree No. 12 of 2020 concerning the Determination of Disaster in the Spread of Corona Virus Disease 2019 (COVID-19) as a National Disaster. The policy was issued to regulate the situation in the country to remain conducive. The impact of the Covid-19 pandemic is very broad and touches on several important sectors in the country, one of which is the economic sector. When the Covid-19 pandemic occurred, the wheels of the economy were hampered. The community cannot carry out activities outside the home freely. Many companies have laid off their employees, of course many companies have canceled contracts against other parties. This is very unsettling for business actors, because the government issued a policy of the Covid-19 pandemic as a national disaster, which means that the country is in a state of force majeure. In response to Presidential Decree No.12 of 2020, business actors who have made contracts with other parties do not automatically cancel contracts with other parties. If this is done, one of the parties will be disadvantaged, because the other party's achievements are not fulfilled. And the other party is definitely considered to have committed default or broken promises. A contract is an agreement made by two or more parties and is binding like a law for the parties, this has been stated in Article 1338 paragraph (1) of the Civil Code. And when making a contract in the contract / agreement clause, the forcemajeure conditions have been stated. So the parties are unable 
to unilaterally cancel the contract even in a force majeure. What the parties can do is review the contract and still fulfill the rights and obligations that have been stated in a contract / agreement.

The force majeure clause in the contract / agreement is intended to prevent losses for the parties involved in the contract / agreement. The elements of force majeure should have in common with the rule of law and court decisions. The types of clauses are (Salim HS, 2005) :

1) Non-exclusive clauses

A non-exclusive clause is a condition which is considered as a force majeure condition which is not special, so that the debtor can claim for force majeure as long as there are agreed conditions for the entry into force of a force majeure.

2) Exclusive Cluster

An exclusive clause is a force majeure condition that is only limited to a condition that has been stated in a mutually agreed agreement.

Even though Article 1245 of the Civil Code states that compensation for losses and interest can be forgiven when a compelling situation occurs. However, the parties who have entered into a contract / agreement must be able to prove that there is an obstacle that really cannot perform their performance. This will be in accordance with the values of justice applied in the law in our country. So what the parties can do is in accordance with Article 1338 of the Civil Code which states that all agreements made in accordance with the law are valid as laws for those who make them. The agreement cannot be withdrawn other than by the agreement of the two parties, or for reasons determined by law. Agreements must be carried out in good faith. Good faith that can be done by the parties is to review the contract / agreement, if something is not suitable then the contract is corrected and adds a clause in it. So even though the Covid-19 pandemic was declared a national disaster by the government which was included in the force majeure category, the parties could not cancel the contract and one party continued to carry out its achievements. Cancellation of a contract can only be done if the covid-19force majeure situation is written in the contract clause. (KUHPerdata Book III).

\section{Conclusion}

Legal Aspects of Agreement / Contract Cancellation in a state of covid-19 force majeure in Indonesia, is carried out in accordance with applicable legal aspects. The government issued Presidential Decree No. 12 of 2020 concerning the Determination of Disaster in the Spread of Corona Virus Disease 2019 (COVID-19) as a National Disaster. However, in accordance with the Civil Code, contract cancellation in a state of force majeure, Article 1245 of the Civil Code states that compensation for losses and interest can be forgiven when a compelling situation occurs. The corona pandemic is used as an argument for a force majeure in a business contract based on Presidential Decree No.12 of 2020 concerning the Determination of Non-Natural Disasters for the Spread of Corona Virus Disease 2019 (Covid-19). This reason is used as the debtor's defense for the nonperformance of a contract due to an unexpected event. The force majeure condition does not necessarily mean the cancellation of a contract, but renegotiations can be carried out to cancel or change the contents of the contract that has been agreed upon, of course, it is hoped that it will run in good faith. A contract must continue to be executed in accordance with its contents in accordance with the provisions of Article 1338 of the Civil Code which states that every agreement made legally applies as law for those who make it. However, the parties who have entered into a contract / agreement must be able to prove that there is 
an obstacle that really cannot perform their performance. And contract cancellation can only be done if this has been stated in the contract / agreement clause. If this has not been stated in the contract / agreement, then you cannot immediately cancel the contract. Because in accordance with Article 1338 paragraph (1) of the Civil Code, it is stated that an agreement / contract is a law for the parties conducting a contract / agreement. So what one party can do is postponement of obligations by reviewing the clauses and adding new clauses so that one of the parties can carry out their achievements. Because the contract is a legal mechanism in society to protect the wishes or expectations of the parties who carry out the contract / agreement.

\section{References}

Abdul Rasyid Salim, Hermansyah, Ahmad Jalis., Business Law for Companies, Theory \& Case Examples. Cet XIII, Jakarta Kencana, 2007.

Ahmadi Miru, Bond Law Explanation of the Meaning of Articles 1233 to 1456 , Jakarta: Rajawali Pers Raja Grafindo Persada, (2016).

Civil Code, Book 3 Chapter V Part 5 Article 1545 \& Civil Code, Book 3 Chapter VII Part I Article 1553.

Coordinating Minister for Political, Legal and Human Rights, Prof. Mahfud MD in his article Explanation of the Force Majeure Problem Due to the Corona Pandemic https://www.hukumonline.com/berita/baca/lt5ea11ca6a5956/penjelas-prof-mahfudsoal-i-force $-\mathrm{m}$ ajeure-iakibat-corona-pandemic? page $=3$.

Elviana Sagala. (2015). Efektifitas Lembaga Penundaan Kewajiban Pembayaran Utang (Pkpu) Untuk Menghindarkan Debitur Dari Pailit. Jurnal Ilmiah “Advokasi” Vol. 03. No. 01. Maret 2015.

H. Amran Suadi, Sharia Economic Dispute Resolution in Theory and Practice , Jakarta: Kencana, (2017).

Ichsan, R. N., Suparmin, S., Yusuf, M., Ismal, R., \& Sitompul, S. (2021). Determinant of Sharia Bank's Financial Performance during the Covid-19 Pandemic. Budapest International Research and Critics Institute (BIRCI-Journal): Humanities and Social Sciences, 4(1), 298-309. https://doi.org/10.33258/birci.v4i1.1594

Mariam Darus Badrulzaman, et al, Compilation of Engagement Law , (Bandung: PT Citra Aditya Bakti, (2016).

Mieke Komar Kaatmadja, Agreement Law, Bandun, PT Alumni, ( 2010 ). Theory and Examples of cases. Cet.III. Jakarta.Kencana, 2007.

Muchtar Kusumaatmadja-Etty R Agoes. Introduction to International Law. Bandung Alumni Publishers. ( 1999 ) .

Peter Mahmud Marzui, Legal Research, Kencana Prenada, ( 2010 ) .

Presidential Decree Number 12 of 2020 concerning the Determination of Non-Natural Disasters for the Spread of Corona Virus Disease 2019 (Covid-19) article https://dinkes.gorontaloprov.go.id/who-tentuk-covid-19-sebagai-pandemi/

Riduan Syahrani, Details and Principles of Civil Law , (Bandung: Alumni, 2006).

Subekti. Legal agreement. Cet XIII. Jakarta. Intermasa, 1991.

Salim HS, Introduction to Written Civil Law (BW). Jakarta. Sinar Grafika. (2005).

Sriono, S. (2019). Tanggung Jawab Pemberi Fidusia Terhadap Benda Jaminan Fidusia Dalam Perjanjian Kredit. Jurnal Ilmiah Advokasi, 07(02), 149-159.

Wawan Muhwan Hariri, Bond Law. Faithful Library. Bandung. ( 2011 ) . 